\title{
Article
}

\section{Making tax and social security decisions: lean and deskilling in the UK Civil Service}

Martin, Douglas

Available at https://clok.uclan.ac.uk/19431/

Martin, Douglas (2017) Making tax and social security decisions: lean and deskilling in the UK Civil Service. New Technology, Work And Employment, 32 (2). pp. 146-159. ISSN 0268-1072

It is advisable to refer to the publisher's version if you intend to cite from the work. http://dx.doi.org/10.1111/ntwe.12092

For more information about UCLan's research in this area go to http://www.uclan.ac.uk/researchgroups/ and search for < name of research Group>.

For information about Research generally at UCLan please go to http://www.uclan.ac.uk/research/

All outputs in CLoK are protected by Intellectual Property Rights law, including Copyright law. Copyright, IPR and Moral Rights for the works on this site are retained by the individual authors and/or other copyright owners. Terms and conditions for use of this material are defined in the policies page.

\section{CLoK}

Central Lancashire online Knowledge www.clok.uclan.ac.uk

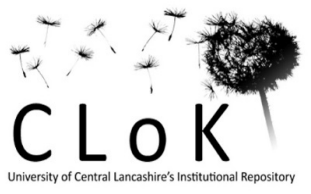


One of the central claims of lean systems of work is the assertion that lean is a means to increase workforce skills (Womack et al., 1990; Ohno, 1988). Lean systems have been advocated on the basis that they promote organizational cultures of continuous improvement (Hines et al., 2004). Lean enables employees to use knowledge of their own jobs to improve organizational efficiency. The assertion that lean promotes greater skill acquisition has been subject to challenge with evidence that lean has led to significant reductions in skills as jobs become increasingly narrowly defined and work is intensified (Pardi, 2008; Stewart et al., 2009). With the expansion of lean systems into the Civil Service as a means of improving standards of performance (Radnor, 2010), the assertion that lean increases skills merits a thorough examination. Previous studies have found that rather than increase skill levels among civil servants, attempts at organizational restructuring have resulted in significant deskilling with evidence of work intensification and reductions in job autonomy (Carter et al., 2011a; Fisher, 2007; Danford et al., 2009).

However, what is missing from previous studies is a detailed analysis of the decision-making functions of civil servants and the impact of lean upon them. The Civil Service has historically had two functions, first, the development of policy and, second, the implementation of policy (Campbell, 1965). The latter function includes not only includes administrative processes, but the judicial or quasi-judicial decision-making responsibilities delegated by the state to its civil servants to exercise on its behalf. This executive function of civil servants involves the use of discretion and judgement in the application of the law (Baldwin et al., 1992). Few studies have examined the exercise of quasi-judicial functions from the perspective of skill and the labour process. Utilising the framework of Mashaw's (1983) model of administrative justice to understand civil servants' job roles, the study will also align the changes in decision-making skills with the other changes in skill in the administration of Civil Service work under a lean regime.

This research, with data taken from office workplaces in two major Civil Service departments, contributes to a debate on the direction of skill within the public sector and the impact of efficiency cuts on the state sector. The capacity of civil servants to administer social security and taxation has an impact not only on the skills levels of a large number of public employees, but on wider society where the public has historically had an expectation of public probity, consistency and fairness from the state apparatus (Robson, 1956).

\section{Lean, the Civil Service and its Decision-Makers}

The arguments relating to lean and its impact on skills are well rehearsed and require only a brief summary. Advocates of lean systems argue that lean working has provided a significant break with previous systems of work organization (Womack et al., 1990). Lean not only arguably provides the potential for more fulfilling jobs through an environment that encourages team working and multiskilling, but expands the repository of skills held by each worker (Ohno, 1988). Hines et al. (2004) emphasise that the lean organization is one that focuses on quality and productivity promoted by organizational learning. Lean is advocated on the basis that it promotes job rotation, multi-skilled employees and gives employees the capacity to analyse and address the roots causes of efficiency problems through a process of continuous improvement (Womack and Jones, 1998). Unlike previous 
work regimes, workers are empowered rather restricted by organizational systems. Employees are thereby able to continuously increase their skill levels in both quality and productivity to the benefit of their organizations. While these earlier accounts of lean largely focus on the use of lean within manufacturing, Womack and Jones (2005) argue lean can be successfully applied into the service sector. The same issues that faced that manufacturing in terms of improving organisational efficiency and quality are those currently faced by the state sector, and accordingly the same type of approach to organisational change has the capacity to improve the delivery of public services (Radnor, 2010).

In contrast, lean systems have been subject to critique due to the ways in which these systems have reduced skill. Lean's tendency towards rigid standardisation allied to work intensification limits the workforce's capacity to exercise discretion and autonomy (Pardi, 2007). The reasons for the failure of lean have on the one hand been attributed to management's misapplication and misunderstanding of the lean ethos (Esbenshade et al., 2016). To that extent, an authoritarian approach to lean is contingent on the context of the firm or sector. With the appropriate levers, the reductions in skills found within a lean environment could be reversed. However, an evaluation of lean focusing on the context of the firm or workplace neglects lean's ideological basis. Reductions in worker skill are an inevitable consequence of lean as employers seek to use lean techniques as a mean of increasing control over the workforce during a period of financial austerity (Stewart et al., 2009; Durand, 2007). To that extent, lean is used against workers' interests not simply within individual workplaces, but also more widely across the whole economy as employers seek to reduce labour costs.

The state sector is not immune from the trends found in the private sector. The implementation of lean into the Civil Service from 2006, initially into HM Revenue and Customs (HMRC), but subsequently into other departments in the wake of the Gershon Review (2004), was premised on the reduction of labour costs and attempts to increase organisational efficiency. The roll out process for lean in HMRC, scheduled for completion by 2013 (National Audit Office, 2011) has been matched by, for example, the utilisation of lean in HM Courts Service (Ministry of Justice, 2009). The rationale for the use of lean was ostensibly based on the changing environment of the organisation and the assertion that there was lack of employee skills in certain critical areas (Radnor and Bucci, 2007). Any deficiencies in the implementation of lean were attributable to HMRC management failing to put the needs of the public at the centre and thus using lean solely as a cost containment exercise rather than primarily as a tool to add value to the service provided (Proctor and Radnor, 2014; Seddon, 2008). However, Carter et al. (2011a) argue that the tightly controlled Taylorised work regime that existed within HMRC reflected that lean systems are fundamentally premised on control of the labour costs. The symptoms of lean working, including diminished task discretion and job autonomy and the devaluation of employees' tacit skills (Carter et al, 2011b), are a direct consequence of the assertion of greater state control over labour costs. The state's use of lean is not primarily about the improved delivery of services, but reflects the need to exercise control as part of neo-liberal restructuring of the state manifested in reduced resources to government departments delivering these services. To this extent, control is integral to lean rather than contingent on the capacity of management to implement it.

The studies to date have focused largely on skill as part of a general suite of abilities that encompasses civil servants' capacity to administer work processes. However, where the direction of skill 
has been under-explored is in relation to decision-making functions. As Sainsbury (2008) highlights, the act of judicial or quasi-judicial decision-making cannot be entirely separate from the manipulation of the administrative procedures by which decisions are promulgated. However, decision-making is a distinct function insofar as it requires the exercise of discretion to a specific end, namely the implementation of the legal process on behalf of the state.

The Civil Service has historically divided work functions between those with the responsibility for the creation and development of government policy under the instruction of the government and those who implement state policy (Campbell, 1965). The vast majority of civil servants, working in around 330 departments, are engaged with the latter function. Since the 1980s, these civil servants have been subject to the results of extensive organizational restructuring and changes in work conditions. Attempts by the state to marketise the public sector have witnessed extensive privatisation of certain areas of civil service work, the use of private sector work practices, and decentralisation of management control to individual departments (Bach and Kessler, 2012; Pyper and Burnham, 2011). The impact has been to change how government departments manage their staff in terms of their human resource policies and how management allocate and control work tasks at a workplace level. The demise of whole case working where employees managed the end-to-end process (Fisher, 2004) and the extensive use of metrics to measure public sector performance has led to increased pressure on civil servants to focus solely on those parts of their jobs that are linked to government targets and to the routinisation of much Civil Service work.

Moreover, there is also an historic division among civil servants engaged in the implementation of state policy between those who have a clerical function and those with an executive function (Campbell, 1965). The latter group was historically assumed to have the capacity to act with discretion and judgement. It is this group of civil servants who have traditionally been decision-makers. In social security adjudication, for example, Baldwin et al. (1992) explained that in terms of decision-making civil servants exercise a quasi-judicial function. This is the legal process whereby civil servants through the application of discretion and judgement apply the law to claims for social security benefits. It is quasijudicial insofar as it lacks some of the investigatory powers of appellate tiers of adjudication. Discretion is embedded into the quasi-judicial function insofar as it is exercised within a set of rules and standards (Harlow and Rawlings, 2006). It assumes the capacity of decision-makers to select the correct course of action exercising expertise and judgement in the application of statute and case law (Freedman and Vella, 2012). However, changes in the legal basis upon which decisions have been made have not necessarily changed how discretion is exercised (Adler, 2006; Sainsbury, 2004, Gulland, 2011). Changes in practice are in part affected by the move to computerisation where the decisions are promulgated through data input (Adler, 2006), but also because of broader political and economic pressures on systems of governance.

Mashaw (1983) argued in his analysis of US social security administration that there were three approaches to administrative justice and the associated decision-making. The first of these, bureaucratic rationality, is premised on delivering "accurate and efficient concrete realizations of the legislative will" (1983:24-25). Decision-makers in this model adjudicate on claims in the most accurate and costeffective fashion trading off the risk of potential errors against administrative and process costs. 
Individual adjudicators engage in gathering, processing and evaluating information within the confines of standardised rules and routines albeit for management the process is treated as technocratic. Mashaw contrasts this model with the professional treatment model where decisions are based on interpersonal relationships with clients and diagnostic intuition. His third model is described as 'moral judgment' where impartial decision-makers arbitrate between competing claims based on underlying moral principles. The interrelationship of the three models existing within one structure is subject to tensions as professional judgment can be undermined by "programmatic rationality" where vocational experts are cast in a subversive light.

Baldwin et al. (1992) argue that the form of decision-making found within social security adjudication in the UK was most closely related to the bureaucratic rationality model. Decision-making relied on the collection of information and the application of statute or case law, but was also constrained by management's need to achieve performance targets and save processing costs. Although most decisions were routine and repetitious, the pressure on adjudication officers to achieve targets had a negative impact on quality of decision-making. Although the majority of Civil Service work matches most obviously with this bureaucratic rationality model, government services also include those whose work is more aligned with the professional treatment model. Advisers in Job Centres have a range of options with which to address clients' employability issues and as such use their professional knowledge to fit individual circumstances. However, as Sainsbury (2008) argues, the pressure to make financial savings in these areas has also reduced the amount of discretion that can be exercised.

Achieving performance targets around employment statistics in effect compromises the quality of the service provided and effectively reduces the discretion of the decision-maker. The model of administrative justice has arguably moved to one that reflects a managerial model where there is increased reliance on standardised and automated decision-making where the capacity to exercise discretion is systematically and deliberately squeezed out (Adler, 2006). Taking its cue from New Public Management, the main features of this model are managerial autonomy, performance standards and audit.

This research evaluates how the increased use of lean systems of work has altered the ways in which social security and taxation decision-makers exercise their skills and to what extent skill levels have increased or decreased. The distinction between the discretionary act of decision-making and the accompanying administrative process are critical in this respect. The research will also argue that the changes brought about by lean are indicative of changes in the model of Civil Service work.

\section{Methodology}

The data for this research was collected from the Public and Commercial Services Trade Union (PCS). PCS had longstanding concerns over deskilling and intensification of work, initially in the wake of the implementation of lean in HMRC and latterly more widely throughout the Civil Service (Gall, 2007). PCS had commissioned the researcher to examine the impact of lean. PCS provided support through its branch structure for the researcher to access participants allied to personal contacts that the researcher had through his previous membership of PCS. 
The initial phase of the research (2008 to 2010), consisting of 15 interviews with senior paid officials and PCS stewards, was devoted to gaining an overview of lean within the Civil Service before the narrowing the focus to HMRC and the Department for Work and Pensions (DWP). These two large government departments were selected due to ease of access, but also because of their widespread use of lean, often in piecemeal fashion. Large business units such as tax processing were often at the forefront of lean implementation although management also introduced lean in smaller self-contained specialised areas of work. A total of 39 PCS stewards and members from DWP and HMRC were interviewed either individually (face to face or by telephone) or in groups over the period May 2010 to June 2011. These interviews were supplemented by attendance at union meetings. With the consent of the participants, most of the interviews were recorded and transcribed with supporting written notes taken.

The 39 interviewees were representative of a range of work duties. Historically only executive grades (EO) would have had authority to make quasi-legal decisions (Campbell, 1965), but increasingly 'simple' decision-making has been devolved to administrative grades or clerical officers (CO) leaving 'complex' decisions, ostensibly based on the exercise of discretion, to executive officers. Table 1 provides detail on job role, grade, gender, length of interview and union role of the interviewees.

The research used a range of proxies to evaluate the direction of skill recognising the multifaceted nature of skill. The interviews were structured to systematically address each of the proxies. The proxies used were substantive job complexity and work autonomy (Spenner, 1983). These have been used extensively within the Skills Survey (British Market Research Bureau, 2006). Job complexity in this study was based around length of training, the amount of time required to consolidate training to achieve proficiency in the role job and task variety each of which should be considered in relation to external circumstances (Field, 1980; Spenner, 1983, Felstead et al., 2004). Reductions in discretion and freedom to act, pace of the job and level of supervision serve as measures relating to the level of job autonomy (Spenner, 1990). With the capacity to exercise discretion central to any form of legal decision-making, these well-established proxies remain valid in evaluating skill changes in the Civil Service.

\section{Decision-making skills and job complexity}

What was first evident in both HMRC and DWP was the reduction in time given to training and consolidation for all aspects of administrative work. However, in terms of decision-making, these trends were also in evidence. Whereas training for certain types of social security had previously been based on an extended period of classroom-based training, there was an on-going trend to change the format and length of training. Where previously training on some of the main social security benefits was based on 13 weeks' classroom attendance, training on Employee Support Allowance was reduced to five weeks training and three weeks consolidation 'on the job'. A further six weeks were then allowed to achieve line manager assurance of competence whereby decision-makers had to assess 50 claims without error. In Social Fund, decision-makers were provided with two weeks of training although staff members were in effect handling telephone applications for crisis loans within two days of the start of the consolidation period. More extreme examples of attempts to curtail training include: 
one of the trainers boasted that they'd managed to get [training] down from three full nights which would have been 15 hours; they'd managed to get it down to 10 hours (steward in HMRC, Interview 9)

However, the more telling factor was a change in the rationale of training and its consolidation under the lean regime.

Consolidation was increasingly geared to handling a very limited range of duties within a very narrow context. The rationale for consolidation activity was increasingly geared towards the development of skills in decision-making in terms of a single aspect of tax or social security. It was not simply that training and consolidation was based on a single job role. There was no longer a presumption by management that successful consolidation of one job role was reliant on understanding where the individual trainee's work fitted with related and dependant job roles. While longer serving civil servants with background knowledge of the work of their departments were better able to adapt to new job roles, newer staff members were significantly more affected by this new rationale. Even within those parts of the Civil Service where the potential for the professional treatment model existed, management constrained the extent to which consolidation of new skills could be applied. One adviser in a Job Centre stated:

this is one of the complaints because a number of our staff when we opened our Jobcentre in 2006 were very good, very knowledgeable about the benefits and one of the great frustrations was that you were told not to use that knowledge, simply to signpost people to phones (Interview 2)

There was little expectation that jobholders required appreciation where their decision-making functions fitted with the wider purposes and organization of their departments. Added to this, specialised training in the complex aspects of decision-making was rare among respondents and absent from the training for simple decision-making.

Fitting consolidation in decision-making skills to meet the confines of individual job functions in isolation to other job roles was to a large degree a consequence of reductions in task variety. Work within HMRC and DWP was increasingly fragmented within and between workplaces. Management allotted tranches of work to separate locations obviating the need to have decision-makers expert in a range of benefits or tax in each location. Even within individual offices, work was streamed into its component specialist areas. The lean regime further exacerbated this trend with its emphasis on standardisation. Accordingly, there was very limited scope for local offices to adopt distinctive working practices to suit local circumstances: offices doing similar types of decision-making become more homogenous in their work organization. There was less scope for management to provide staff members with a range of duties with less capacity for interchangeability across different decisionmaking disciplines. There was restricted scope for task variety within individual job roles. One Social Fund Officer in ironic tone said:

I do Community Care Grants and I do Community Care Grants and then if I'm lucky I'll do a Community Care Grant (Interview 1) 
These reductions in variety were both antecedent to the introduction of lean systems in HRMC and DWP, but also central to the implementation of lean. With work previously subject to fragmentation, reductions in task variety were evident before lean was rolled out, but the implementation of lean made it easier to reduce task variety still further. The fragmentation of work in effect begets further fragmentation. The areas where lean was less embedded retained more of the earlier model of work where civil servants had the capacity to switch between different types of decision-making albeit within the same broad area. With management intent under the lean regime to centralise blocks of work, decision-makers were effectively restricted to dealing with a limited range of activities.

Of those interviewed, around two third of interviewees confirmed that job complexity had reduced over the previous five years. Remaining interviewees had seen no change or had experienced an increase in job complexity. Factors in maintaining or increasing job complexity included promotion and transfer between departments. However, the other mitigating factor that contributed to retaining elements of job complexity reflected the modifications and judgements that decision-makers needed to make in applying the law to individual taxpayers or social security claimants.

Respondents referred to the complexity engendered by the need to deal with the public whose circumstances were significantly more complex than HMRC and DWP management seemed prepare to consider. One administrative officer in DWP referred to the problems he encountered when dealing with callers at the Job Centre:

You're interfacing with the public and within that group of the public a significant minority of people who, as you say, have chaotic lifestyles who actually may present at the Jobcentre in a disinhibited fashion (Interview 21)

Attempting to make appropriate decisions for those whose circumstances are complex makes the job function more complex than that conceived by management. Allied to this, the legislation under which decision-makers are expected to operate and facts of any individual tax or social security benefit both contain elements of complexity. Even with lean systems premised on filtering work into streams that sought to remove the need to deal with complex issues, these systems did not sift out complex issues. One tax officer in HMRC stated that his job assumed he would only ever deal with 'clean debt', but in reality, both the individual facts of the case and the law created complexity hindered by his lack of legal training.

Nonetheless, while these mitigating factors sustained some job complexity, what was apparent was the pressure that lean working had in the opposite direction to simplify jobs. The more vigorously management applied lean and the more embedded lean became, the greater the reductions in job complexity became.

While the situation around job complexity was not wholly bleak, the picture in terms of work autonomy and decision-making was much more negative for reasons that will become apparent. 


\section{Decision-making skills and autonomy}

Decision-making is never unfettered within the Civil Service. Fundamental to the adjudication process is the premise that decisions are made within the limits imposed by legal requirements. In addition to statute law, decision-makers follow supporting guidance issued by their departments to assist with the decision-making process. However, the decision-making process presumes the conscious application of rules and guidance to any given social security or tax claims. Discretion is thereby embedded into the decision-making process even if decisions have only binary outcomes. However, as Baldwin et al. (1992) highlight, adjudicating officers historically did little "adjudication": most decisions were done de facto by administrative officers. Discretion was often implicitly exercised rather than consciously expressed as a formal act. While there was variety in practice with some types of decision-makers more conscious of the legal basis of their decisions (in the interviews, Social Fund Officers often referred to specific parts of the legislation), the research found limited evidence of the exercise of the explicit use of discretion.

In HMRC and DWP, levels of discretion varied according to the specific area of work. Some of the areas of work were not complex and decisions were mundane requiring little discretion. The shift to downgrade simple decision-making to administrative officers whose training largely related to the administrative processes of the decisions rather than understanding their legal basis meant for the most part that decision-making was treated as an automated process. Elements of the different administrative jobs retained the exercise of some specialised knowledge. However, use of discretion where decision-makers had the capacity to purposively select from two or more courses of action each potentially valid on its own merits was rarer. For the most part, decisions were promulgated through inputting data to a computer system rather than an explicit act of decision-making. Advisers in the Job Centres did have a menu of activities to which they could refer job seekers and Social Fund Officers relied on the exercise of judgment in allocating funds from a discretionary fund. Nonetheless, the understanding of management of the parameters under which staff members operated was limited even within these areas of work. One Social Fund Officer stated:

you could look at guidance, you could get two people looking at it and come up with the different decisions. You can still do that just now, but I think [management] would be surprised if you came up with different decisions for the same type of case (Interview 3 )

While there was no evidence found to indicate that managers were directly subverting the decisionmaking process, pressures were placed on staff members to take a stricter approach in such areas as job seeking. It was into this changing environment of decision-making that lean was implemented.

While lean systems were never ostensibly used to influence the content of decisions, lean was a significant contributory factor in increasing the pace of decision-making. Cuts in Civil Service staffing of around 21\% over the period 2006 to 2014 (Office for National Statistics, 2016) are clearly relevant with less people available to undertake work functions, but for individual PCS members at a workplace level, the increasing pace was manifested in a number of ways. There was extensive use of standardised forms and electronic systems to facilitate the decision-making process. These forms were implemented by management on the basis that these would speed up the decision-making process. The electronic 'handoffs' between one part of the computer system and another accelerated the pace of work. The speed of 
decision-making was also significantly affected by management's use of often arbitrary performance targets rather than the need to ensure that the public had quality decisions. Baldwin et al. (1992) had identified this paradox as a longstanding issue within the Civil Service, but in the changing environment of computerisation and the adoption of lean working, the pace of work was accelerated.

Increased speed of decision-making did not necessarily equate to increased quality. One Social Fund Officer commented on lean decision-making templates that he and his colleagues were expected to use. The templates had been trialled at another location and rolled out to his site. These templates were not ultimately used, but presaged the introduction of electronic lean forms. He said:

we saw some of these [name of location] decisions and they were possibly some of the worst things you could possibly see and I think it died a death. I mean electronic [forms] for [Community Care Grants] did come in, but when it came in last year decision-makers ended up taking twice as long [laughs] to do decisions using this one, [...] and that was supposed to be a lean document (Interview 3)

Furthermore, performance targets were sometimes based on factors unrelated to the quality of the decision. In the Social Fund call centres, performance targets were based on the number of calls answered daily, not primarily on the quality of the decision. The temptation was for call handlers to manipulate the statistics by treating a proportion of calls as "inappropriate" and curtailing those calls: claimants were advised at the outset of the call that their applications would be unsuccessful or be refused the opportunity to apply on spurious grounds (for example failing to quote a home postcode correctly). By denying someone a decision, it also denied that person the accompanying appeal rights (Department for Work and Pensions, 2013). The pressures placed on staff members, backed up by threats of poor performance appraisal reviews for those who failed to achieve targets, effectively impacted on the quality of the legal process. The reductions in staff numbers meant that lean systems ostensibly implemented by management as a means of improving the quality of service were used instrumentally only to the extent that they achieved performance targets. Lean techniques such as focus groups and performance improvement boards were manipulated by managers at local office level to reduce the time available to undertake decision-making activity. This 'guerrilla lean', as one senior trade officer named it, in one example was manifested where the local lean champion reduced the time allocated for individual job seeker interviews. Despite the fact that longer interviews were valued by staff members in assisting people with their job search activities, the reductions in the number of staff available, allied to the performance targets potentially missed by extended interviews, outweighed the value of the quality of decisions reached.

Social Fund decision-makers were at the 'sharp end' of the increases in pace and electronic supervision systems used in the DWP telephony systems. However, across DWP and HMRC it was evident the reductions in skill in decision-making were significantly more in evidence in terms of losses of autonomy than they were in terms of job complexity. In those areas where lean was embedded, such as the tax processing centres in HMRC, decision-makers were significantly more subject to deskilling than in those areas of the Civil Service where lean was more 'light touch'. These embedded lean areas included routine and repetitious decision-making and areas where there was scope for decision-makers 
to select between different courses of action. Although on one level, legal requirements safeguarded the quality of the decisions reached, an amalgamation of reduced levels of discretion and increasing pace of work in effect reduced the levels of autonomy and control that decision-makers had over their quasi-legal responsibilities. It was noticeable there was no evidence to suggest that management used lean to interfere with the content of decisions. Lean systems in the Civil Service were used primarily to affect the process of reaching decisions rather than their content, but it is impossible to separate the promulgation of decisions from the process by which those decisions were reached.

\section{Discussion and conclusion}

In DWP and HMRC, the tools and techniques of lean were central to reducing job complexity and autonomy. These factors, proxies for the reduction in skills, are congruent with recent trends across the UK post 2006 where there has been an increase in work intensification (Gallie et al., 2013). The current study builds on the study of Carter et al. (2011a) to show that significant instances of deskilling were not confined to one area of Civil Service work. What is striking about this current study of decision-making is that even in areas ostensibly protected by legal or quasi-legal requirements skill levels were reduced. Changes in the training regime, work standardisation and reduced staff numbers were significant factors. Allied to this, senior management increasingly used the EO grade, not as technical decisionmaking experts, but as people whose role was primarily to performance manage subordinate staff (Carter et al., 2013). All of these factors diminished the capacity of the decision-makers to reach appropriate and independent decisions. Politically, the purity of decision-making was notionally sacrosanct and interviewees were generally very protective of their belief in the quality of their decisionmaking. However, in practice management's use of lean had a significant impact on the process of decision-making.

The distinction between process and content is significant, but in practice, it is also blurred. The lack of previous work on decision-making may in part reflect that the distinction between content and process is artificial in the practice. This is more evident in some areas than in others. In areas of simple decision-making, the promulgation of a decision is largely indistinguishable from the data input that produces the decision for the public. For more complex areas of decision-making, the legal or quasi-legal process has a distinct entity. Decision-makers were here more obviously aware of the distinction between process and content. Social Fund Officers and specialist tax officers either referred to the specific parts of legislation by its correct terminology or had a clear appreciation of the specific legal principle on which their decisions were reached. In the areas where professional judgment was exercised, for example advisers in a Job Centre, there was also a distinction between process and content as the individual circumstances of the public were identified and assessed. Nonetheless, irrespective of the degree to which civil servants distinguished between content and process, HMRC and DWP management accelerated the blurring of these lines using lean working.

Increasingly, Civil Service management premised their treatment of tax and social security decision-making on the efficiency of the administrative processes. Lean was central to addressing more efficient and quicker ways of dealing with these areas of work. There is a danger of examining the past through rose-tinted spectacles imagining a 'golden age' of adjudication where decision-makers engaged 
in pure adjudication freed from the burden of administrative processes. However, management pressures on staff members to attain targets and the historic blurring of the distinction between administrative procedures and decision-making was, as Baldwin et al. (1992) testify, always present. However, lean with its emphasis on standardisation and the substitution of individual discretion with greater control over the labour process has done two things.

First, it has placed greater emphasis on performance targets, often unrelated to the quality of the substantive quasi-legal decisions that these are supposed to represent. There was a clear reduction in the amount of discretion that decision-makers could exercise as the time allocated to the collation of information required to reach an appropriate decision and the time to consider the full implication of outcomes was reduced. This was allied to the presumption of management that all decisions were capable of only one interpretation. In some cases, the simplification of the legislation and the increasing promulgation of decision by computer were significant in this respect. However, the pressure to reduce all decisions to binary options rather than take into account the complexity of individual circumstances and different interpretations of the facts and law was increasingly a feature of the quasi-legal decisionmaking process. Due to management pressure, it was increasingly evident that civil servants often had to compromise the amount of time they could allocate to each decision. There was a sense of resignation to the tone of many of the interviews where decision-makers, knowing the consequence of failing to meet a performance target, had to compromise the legal quality of their decisions. With union stewards stretched often dealing with individual case representation and the pressure of their Civil Service work, there was very limited scope for PCS members, either individually or collectively, to challenge this new regime.

Second, lean had the impact of purposively conflating the quasi-legal decision-making processes with the administrative processes thereby in practice eliminating the distinction between the two. In effect, lean was used to treat all aspects of Civil Service work as administrative processes. It comes as no surprise that the types of deskilling explored by Carter et al. (2011a) in the HMRC tax processing centres were as prevalent in this study among decision-makers as they were among those staff members involved in administrative work. Deskilling became more prevalent as lean sought to remove the vestiges of discretion in decision-making. In terms of the training provided to new decision-makers, the amount of consolidation and the narrow focus of the jobs undertaken, management used lean working to deskill decision-making where the efficiency of the administrative process, itself subject to significant deskilling, was paramount. With ever-decreasing numbers of staff and increasing performance targets, the pressures to further deskilling accelerated.

Baldwin et al. (1992) describe the model of administration found within the DWP of the early 1990s as bureaucratic rationality. Lean systems have arguably not only embedded this model even further into the management system of the Civil Service, but this has been at the expense of attempting to eliminate elements of the professional treatment model. The tensions within the co-existing models of social security administration that Mashaw (1983) described continue to be relevant in the current environment. Lean systems emphasise the process of applying tax and social security decisions at the expense of professional judgement or expertise in decision-making. What is evident from this research is that the tensions previously evident in the UK Civil Service where performance targets were central to 
decision-making have become even more apparent. With training and consolidation of skills based around a narrow range of duties and a regime of standardised work made to fit a lean agenda, management have devalued both professional judgment and the use of discretion in the decisionmaking process. The attainment of performance targets becomes the central measure of valid decisionmaking rather the quality of the decisions themselves. It is in the blurring of the distinction between process that supports decision-making and the outcome or content of any decision where the shift towards a different model of the Civil Service is seen. Process is the aspect that is most easily susceptible to measurement while content may require judgment to validate its worth. Hence, rather than measure the discretionary element of the work, Civil Service management use process measures to validate the quality of the decisions. With declining staff numbers and a lean regime squeezing more out of less, management can manipulate the targets to gain greater control of the labour process.

The model of work found in HMRC and DWP is arguably not simply one based on bureaucratic rationality, but in line with Adler (2006), is a managerial one. Adler completed his work in the period before lean was used. The trend towards the use of performance targets and the paramountcy of managerial autonomy is now even more clearly evident. The emphasis on compliance with standardised rules is also important, but where this is particularly relevant in terms of the lean regime is the way that compliance to the rules of the decision-making is cast by management leaving increasingly less scope for civil servants to interpret the rules independently of their management. With the narrowing of the skill base in training and consolidation allied to limitations of the application of discretion, decision-making skills are set in a spiral of decline. The lean regime that premises the managerial model of work over other models of administration is thus central to the decline of decision-making skills.

Nonetheless, the evidence shows a continuing residue of skills in both HRMC and DWP within its decision-making function. Despite the reductions in discretion and autonomy, decision-makers proved capable of addressing both factually and legally problematic matters often in the face of management's limited cognizance of inherent complexities within the tax and social security systems. The public arena of social security and tax is subject to debate particularly under the neo-liberal regime. However, at very least there is an expectation by the public that civil servants implementing state policy have the skills to apply the law to allow tax payers and social security claimants appropriate appeal rights. The decline in skills has the potential not only to reduce the quality of the decisions made, but, as the research has shown, in some instances denied legal rights of appeal or redress.

The future of skills within HMRC and DWP remains unclear. It is beyond the scope of the article to examine the ways that legislation itself is being simplified and how that will impact on skills. Since the conclusion of this research, aspects of the Social Fund were abolished eliminating social security benefits that were based on the exercise of decision-making discretion. To some extent, the impact of new tax rules and social security benefits must remain speculative. The extent to which the PCS has been successful in fighting to uphold the skills of its members is a significant issue, but also remains beyond the scope of this article. What this research does highlight is that the leaning of decision-making is but one further element of the restructuring of the state sector. The changes in decision-making are symptomatic of a move from a primarily bureaucratic rationality model to a managerial one. The research confirms that even with the limited protection afforded to decision-makers to apply their 
discretion independently of management pressure that no part of the labour process is left untouched by lean. Increased use of lean is not a source of optimism for the future: the implementation of lean in HMRC and DWP has led to significant deskilling among decision-makers. In the current environment where a managerial model of administration currently predominates, the challenge for the general public, civil servants and trade union alike is how to reverse this trend.

\section{References}

Adler, M., (2006), 'Fairness in context', Journal of Law and Society 33, 4, 615-638

Bach, S. and Kessler, I., (2012), The Modernisation of Public Services and Employee Relations: Targeted Change, Basingstoke, Palgrave Macmillan

Baldwin, J., Wikely, N. \& Young, R., (1992), 'Judging Social Security: The Adjudication of Claims for Benefit in Britain', Oxford: Clarendon Press

British Market Research Bureau, (2006), 2006 Skills Survey: Technical Report, University of Kent: BMRB Limited

Campbell, G., (1965), The Civil Service in Britain, (2nd edition), London: Gerald Duckworth

Carter, B., Danford, A., Howcroft, D., Richardson, H., Smith, A. \& Taylor, P., (2011), " 'All they lack is a chain': lean and the new performance management in the British civil service", New Technology, Work and Employment 26, 2, 83-97

Carter, B., Danford, A., Howcroft, D., Richardson, H., Smith, A. \& Taylor, P., (2011), Lean and mean in the civil service: the case of processing in HMRC, Public Money and Management 31, 2, 115-122

Carter, B., Danford, A., Howcroft, D., Richardson, H., Smith, A. \& Taylor, P., (2014), "'They can't be the buffer any longer': front-line managers and class relations under white-collar lean production." Capital and Class, 38, 2, 323-343

Danford, A., Durbin, S. \& Richardson, M., (2009), "'You don't need a weatherman to know which way the wind blows': public sector reform and its impact upon climatology scientists in the UK", New Technology, Work and Employment, 24, 3, 215-229

Department for Work and Pensions, (2013), Social Fund Guide, London: Crown Copyright

Durand, J., (2007), The Invisible Chain: Constraints and Opportunities in the New World of Employment, Basingstoke: Palgrave Macmillan

Esbenshade, J., Vidal, M., Fascilla, G. and Ono, M., (2016), Customer-driven management models for choiceless clientele? Business process reengineering in a California welfare agency. Work, Employment and Society, 30, 1, 77-96

Felstead, A., Gallie, D. \& Green, F., (2004), 'Job complexity and task discretion: tracing the direction of skills at work in Britain', in Warhurst, C., Grugulis, I. \& Keep, E. (eds), The Skills That Matter, Basingstoke, New York: Palgrave Macmillan, pp.148-169 
Felstead, A., Gallie, D., Green, F. and Inanc, H. (2013), Work Intensification in Britain. First Findings from the Skills and Employment Survey 2012, London: LLAKES, Institute of Education

Field, A., (1980), 'Industrialization and skill intensity: the case of Massachusetts', Journal of Human Resources, 18, 2, 149-175

Fisher, M., (2004), 'The crisis of civil service trade unionism: a case study of call centre development in a civil service agency', Work, Employment and Society, 18, 1, 157-177

Fisher, M., (2007), 'The new politics of technology in the British Civil Service', Economic and Industrial Democracy, 28, 4, 523-551

Freedman, J. \& Vella, J., (2011), 'HMRC's management of the U.K. tax system: the boundaries of legitimate discretion', in Evans, C., Freedman, J. \& Krever, R. (eds), The Delicate Balance: Tax, Discretion and Rule of Law, Amsterdam: IBFD, pp.79-119

Gall, G., (2007), Lean and Job Design, London: PCS

Gallie, D., Felstead, A. \& Green, F., (2004), 'Changing patterns of task discretion in Britain', Work, Employment and Society, 18, 2, 243-266

Gershon, P., (2004), Releasing resources to the front line: independent review of public sector efficiency, London: The Stationery Office

Gulland, J., (2011), 'Ticking boxes: decision-making in Employment and Support Allowance', Journal of Social Security Law, 18, 2, 68-86

Harlow, C. \& Rawlings, R., (2006), Law and Administration, (2nd edition), Cambridge: Cambridge University Press

Hines, P., Holweg, M. \& Rich, N., (2004), 'Learning to evolve: a review of contemporary lean thinking', International Journal of Operations and Production Management, 24, 10, 994-1011

Mashaw, J., (1983), Bureaucratic Justice: Managing Social Security Disability Claims, New Haven: Yale University Press

Ministry of Justice, (2008), Simplification Plan, London: Ministry of Justice

National Audit Office, (2011), PaceSetter: HMRC's programme to improve business operations, London: The Stationery Office

Office for National Statistics, (2016), Civil Service statistics, accessed 01/02/2016, URL: http://www.ons.gov.uk/ons/rel/pse/civil-service-statistics/index.html

Ohno, T., (1988), Toyota Production System: Beyond Large-Scale Production, Cambridge, Mass.: Productivity Press 
Pardi, T., (2007), 'Redefining the Toyota Production System: The European side of the story', New Technology, Work and Employment, 22, 1, 2-20

Proctor, S. \& Radnor, Z., (2014), 'Teamworking under Lean in UK public services: lean teams and team targets in Her Majesty's Revenue \& Customs (HMRC)', International Journal of Human Resource Management, 25, 21, 2978-2995

Pyper, R. and J. Burnham (2011), 'The British Civil Service: Perspectives on 'Decline' and 'Modernisation', British Journal of Politics and International Relations, 13, 2, 189-205

Radnor, Z., (2010), 'Transferring lean into government', Journal of Manufacturing Technology Management, 21, 3, 411-428

Radnor, Z. \& Bucci, G., (2007), Evaluation of Pacesetter: Lean, Senior Leadership and Operational Management Within HMRC, London: HM Revenue and Customs

Robson, W., (1956), Bureaucracy and Democracy, in Robson, W. A. (ed), The Civil Service in Britain and France, London: Hogarth Press, pp.1-15

Sainsbury, R., (2004), 'Whatever happened to the reform of decision making and appeals?', Benefits, 39, $12 / 1,8-12$

Sainsbury, R., (2008), 'Administrative justice, discretion and the 'welfare to work' project', Journal of Social Welfare and Family Law, 30, 4, 323-338

Seddon, J., (2008), Systems Thinking in the Public Sector: the Failure of the Reform Regime...and a Manifesto for a Better Way, Axminster: Triarchy Press

Spenner, K., (1983), 'Deciphering Prometheus: temporal change in the skill level of work', American Sociological Review, 48, 6, 824-837

Spenner, K., (1990), 'Skill: meanings, methods and measures', Work and Occupations, 17, 4, 399-421

Stewart, P., Richardson, M., Danford, A., Murphy, K., Richardson, T. \& Wass, V., (2009), We Sell Our Time No More: Workers' Struggles Against Lean Production in the British Car Industry, London: Pluto Press

Womack, J. \& Jones, D., (1998), Lean Thinking: Banish Waste and Create Wealth in Your Corporation, London: Touchstone Books

Womack, J. \& Jones, D., (2005), Lean Solutions: How Companies and Customers Can Create Value and Wealth Together, London: Simon \& Schuster

Womack, J., Roos, D. \& Jones, D., (1990), The Machine that Changed the World, New York: Rawson Associates 
Table 1

\begin{tabular}{|c|c|c|c|c|c|c|}
\hline Interview & DWP/HMRC & $\begin{array}{l}\text { Job Role: } \\
\text { Decision- } \\
\text { maker }(\checkmark)\end{array}$ & Grade & Gender & $\begin{array}{l}\text { Length of } \\
\text { interview } \\
\text { (minutes) }\end{array}$ & Union role \\
\hline 1 & DWP & $\checkmark$ & EO & Male & 82 & Member \\
\hline 2 & DWP & $\checkmark$ & EO & Male & 43 & Steward \\
\hline 3 & DWP & & Higher EO & Male & 71 & Steward \\
\hline 4 & DWP & $\checkmark$ & EO & Male & 84 & Member \\
\hline 5 & DWP & & $\mathrm{CO}$ & Male & 58 & Steward \\
\hline 6 & HMRC & $\checkmark$ & EO & Female & 66 & Member \\
\hline 7 & DWP & $\checkmark$ & EO & Male & 93 & Steward \\
\hline 8 & DWP & $\checkmark$ & EO & Male & 44 & Steward \\
\hline $\begin{array}{l}9 \text { (Group of } \\
\text { 3) }\end{array}$ & HMRC & & $\mathrm{CO}$ & $\begin{array}{l}2 \text { Male, } 1 \\
\text { Female }\end{array}$ & 64 & Stewards \\
\hline 10 & HMRC & & $\mathrm{CO}$ & Male & 66 & Steward \\
\hline 11 & DWP & & $\mathrm{CO}$ & Male & 66 & Steward \\
\hline 12 & DWP & & $\mathrm{CO}$ & Male & 45 & Steward \\
\hline $\begin{array}{l}13 \text { (Group of } \\
4)\end{array}$ & DWP & $\checkmark$ & $\mathrm{EO}$ and $\mathrm{CO}$ & Male & 60 & Stewards \\
\hline 14 & HMRC & $\checkmark$ & EO & Male & 66 & Steward \\
\hline 15 & DWP & $\checkmark$ & EO & Male & 10 & Steward \\
\hline 16 & HMRC & & $\mathrm{CO}$ & Male & 48 & Steward \\
\hline 17 & DWP & & $\mathrm{CO}$ & Female & 49 & Steward \\
\hline 18 & DWP & $\checkmark$ & $\mathrm{CO}$ & Male & 68 & Steward \\
\hline 19 & DWP & $\checkmark$ & EO & Female & 66 & Steward \\
\hline 20 & DWP & & $\mathrm{CO}$ & Male & 43 & Steward \\
\hline
\end{tabular}




\begin{tabular}{|l|l|l|l|l|l|l|}
\hline 21 & DWP & & CO & Male & 76 & Member \\
\hline 22 & DWP & $\checkmark$ & EO & Male & 46 & Member \\
\hline 23 & DWP & $\checkmark$ & EO & Male & 61 & Steward \\
\hline 24 & DWP & $\checkmark$ & EO & Female & 38 & Member \\
\hline 25 & DWP & $\checkmark$ & EO & Female & 38 & Member \\
\hline 26 & DWP & & EO & Female & 21 & Steward \\
\hline 27 & DWP & $\checkmark$ & CO & Female & 21 & Steward \\
\hline
\end{tabular}

* In addition, there was a group interview of DWP branch committee members consisting of both male and female EOs and COs, DMs and non-DMs, lasting 30 minutes. 